\title{
THE CONVERGENCE OF FINANCIAL AND MANAGEMENT ACCOUNTING IN POLAND
}

\section{Przemysław Kabalski, Ewelina Zarzycka}

University of Lodz, Faculty of Management, Lodz, Poland

e-mails: pkabal@interia.pl; ezarzycka@uni.lodz.pl

(C) 2018 Przemysław Kabalski, Ewelina Zarzycka

This is an open access article distributed under the Creative Commons Attribution-NonCommercial-NoDerivs license (http://creativecommons.org/licenses/by-nc-nd/3.0/)

DOI: $10.15611 /$ fins.2018.2.01

JEL Classification: M41, M10

\begin{abstract}
The aim of this article is to present the results of a study on the convergence of financial accounting and management accounting in companies operating in Poland against the background of international solutions. The survey, carried out in 2017, was used to collect data. Based on the questionnaire returned by 40 companies, it was found that the level of convergence of financial accounting and management accounting in Polish enterprises is moderate. The number of worldwide studies on the convergence of accounting is very limited, and in Poland they are quite unique. For this reason, the study presented in this article is relevant both for science and the practice of accounting.
\end{abstract}

Keywords: convergence, management accounting, financial accounting.

\section{Introduction}

The term convergence means, among other things, merging or making something merge. In relation to financial accounting and management accounting, convergence refers to the merger of those two areas (a state) or the creation of this merger (a process). The convergence of financial accounting and management accounting started to take place in enterprises mostly due to the impact of the International Financial Reporting Standards (IFRS), which changed the traditional orientation of financial accounting from retrospective and based on historical costs to prospective and based on fair value.

The aim of this article is to present the results of a pilot study on the convergence of financial accounting and management accounting in companies operating in Poland against the background of international solutions. The objective of the study was to determine the level of convergence of financial accounting and management accounting in particular areas in companies operating in Poland. The received results were compared with the level of convergence in German companies presented in the study of Weißenberger and Angelkort [2011]. For this purpose, a survey 
questionnaire was created based on the study by Weißenberger and Angelkort [2011]. The number of worldwide studies on the convergence of accounting is very limited, and in Poland they are quite unique. Consequently, the study presented in the article reduces the existing research gap. The problem of convergence of accounting is also significant for practical reasons.

The first part of the article contains a review of the literature on the convergence of financial accounting and management accounting. Next, the article presents the methodology and results of the study, as well as the conclusions formed on their basis. The article ends with a summary.

\section{The literature on the convergence of financial accounting and management accounting}

The first empirical study on the relations between management accounting and external reporting was conducted by Joseph et al. [1996; cf. Zarzycka 2016, p. 158]. It turned out that in the analysed companies operating in the United Kingdom, strong tendencies could be observed towards the integration of financial and internal reports and systems of financial accounting and management accounting. The process of convergence of accounting in Austrian companies was extensively described by Weißenberger and Angelkort [2007]. They first presented the traditional relation between financial accounting and management accounting, in which both of these subsystems were completely separated. There were two separate cost areas and two separate databases. Information for financial accounting purposes included income and costs recognised on a cash basis, while for management purposes, relevant revenues and costs were used. Financial accounting reported to the Chief Financial Officer, while management accounting reported to the Chief Executive Officer [Weißenberger, Angelkort 2007, pp. 2-3]. In order to examine the process of convergence of accounting in Austrian companies, Weißenberger and Angelkort developed a survey which in mid-2006 was sent to all the 159 Austrian companies that were known to use the IFRS. They obtained 51 responses that were useful in the study. They found that the integration of financial accounting and management accounting was not complete (the level of integration grows in line with the level in the organisational structure of the company). In their conclusion, Weißenberger and Angelkort [2007, pp. 5-14] stated that the level of co-dependence between the IFRS and management accounting will probably grow in the coming years.

The fact that the number of German companies in which the external and internal accounting are harmonised is growing was described by Hoffjan, Nevries and Stienemannem [2009]. In their opinion, this was related to the use by the corporations operating there (in particular, multinational corporations such as Siemens, Bayer and Daimler) of the IFRS or the American accounting standards (US GAAP). According to the authors, the possibility of convergence of accounting is due to the nature of modern accounting standards, which makes information on 
the results of the company's business activity collected for financial reports useful for management purposes. In this situation, there is no need to keep double accounts of costs and results.

The convergence of accounting in Germany was also a subject discussed by Sobańska [2010, p. 98]. She drew attention to the fact that the shift from two cost areas to one meant the need to provide the controlling department with information generated by external accounting for the purpose of profit management. In turn, information from the controlling system became necessary for creating the numerous estimates required by the IFRS. In this way, German companies implemented solutions in line with the Anglo-Saxon model of accounting, in which the accounting system is composed of integrated areas of financial accounting and management accounting.

Taipaleenmäki and Ikäheimo [2009] conducted a study and an analysis of the causes, nature and consequences of the convergence of accounting taking place in technical (based on integrated IT tools), organisational and behavioural aspects. The authors indicated the following signs of the convergence of financial accounting and management accounting in the companies taking part in the study:

- integration of IT systems for data gathering and processing (according to the researchers, this is a precondition for convergence in the organisational and behavioural area),

- synchronisation of the process of financial accounting and management accounting (e.g. by harmonising the reporting dates and deadlines for providing particular information),

- the accounting specialist performing both managerial and financial accounting tasks, which requires knowledge in both areas; such an accountant plays a hybrid role of super-accountant and can even hold the position of Chief Executive Officer.

Taipaleenmäki and Ikäheimo think that the process of convergence of financial accounting and management accounting will continue, even believing that the full integration of these two areas may be possible in the future.

The phenomenon of convergence of financial accounting and management accounting as a result of adopting the IFRS was investigated by Procházka [2011] in the case of the Czech Republic. In his opinion, adopting the IFRS by Czech companies stimulated the development of management accounting, which previously had been poorly developed. The information created for the purpose of the IFRS also proved useful in company management.

Weißenberger and Angelkort [2011] also examined the impact of integration of accounting management and financial management on the efficiency on controlling in German companies. They discovered a moderate correlation between the level of integration of financial accounting and management accounting systems and the following three variables: the coherence of the financial language, the quality of the services provided, and the impact on the managers' decisions. The study of 
Weißenberger and Angelkort inspired another study conducted in Brazil by Dani and Beuren [2014]. Those authors indicated that, in the analysed companies, the integration of financial accounting and management accounting under the influence of the IFRS increases the effectiveness of the controlling department.

In Poland, apart from Sobańska, the issue of the convergence of financial accounting and management accounting was analysed by Kabalski [2012]. He distinguished two types of convergence, depending on the level of management accounting before implementing the IFRS. In situations in which management accounting was well-developed before applying the IFRS, the information created for management accounting purposes over a long period of time was also used for financial reporting purposes. The management accounting database automatically became the source of information for financial accounting. Kabalski [2012] called it the convergence (merging) of financial accounting with management accounting. If management accounting is not well developed, implementing the IFRS stimulates its development. In such cases we are dealing with the induction of management accounting under the influence of the IFRS.

Kabalski [2012] was the first researcher in Poland to conduct a study on the convergence of financial accounting and management accounting in 2011. Inspired partly by the studies of Weißenberger and Angelkort [2007], Kabalski created a survey questionnaire composed of 10 questions directed to companies using the IFRS. He obtained only 13 correctly completed questionnaires. In five out of the13 companies, integration of the internal systems of financial accounting and management accounting took place (they used to be separate). In $77 \%$ of the surveyed companies, synchronisation of the processes of financial accounting and management accounting took place (e.g. by harmonising the dates of external and internal reporting, and harmonising the deadlines for providing particular information). Moreover, in $62 \%$ of the surveyed companies, accounting specialists conducted tasks both in the area of management accounting and financial accounting and in only four out of the 13 companies, the area of IFRS financial reporting and management accounting (controlling) were managed by the same entity.

Due to the fact that six years have passed since the study carried out by Kabalski and, most of all, that the scope of the study was very limited, we decided to conduct a study on the convergence of financial accounting and management accounting in Polish companies. The methodology of an empirical study and its results are presented in the following sections of the article.

\section{The objective and methodology of the empirical study}

The objective of the study was to determine the level of convergence of financial accounting and management accounting in particular areas in companies operating in Poland, and to compare this level with the level of convergence in German companies [Weißenberger, Angelkort 2011]. For this purpose a survey questionnaire 
was created based on the study by Weißenberger and Angelkort [2011]. It was to measure the level of convergence in five areas (planning and budgeting, reporting, performance measurement, IT systems, and organisation of the accounting system within the company), and to measure the index of convergence (the overall level of convergence in the analysed companies). The questionnaire was composed of two parts. The first part contained questions concerning the respondent and the company he or she represents. The second part concerned convergence. The convergencerelated part contained 15 questions aimed at determining the level of convergence in the area of planning and budgeting, reporting, performance measurements, the IT systems used, and other aspects of the organisation of the accounting system in the surveyed companies. The respondents provided answers to the questions by entering a number from 0 to 5 in the corresponding section; 0 meant that they agreed with a given statement to a very limited extent, while 5 meant that they agreed with it to a very high extent.

The collected data were then analysed statistically. In the analysis, based on the average, the standard deviation and the structural indicators for particular answers, the level of convergence was determined for particular areas. The next step in the analysis was to calculate the convergence index for particular areas. This was established for each of the analysed areas based on the average of the answers provided by the respondents to questions from a given area. The following ranges were assumed for the purpose of assessing the level of convergence:

$0 \leq$ index $\leq 2$ : (very) low convergence

$2<$ index $<4$ : moderate convergence

$4 \leq$ index $\leq 5$ : (very) high convergence

\section{The course and the results of the empirical study}

The survey was carried out in 2017. A sample of 1200 companies was selected randomly in a simple random sampling conducted on the Tax Identification Numbers (NIP) available in the database. Then, a request was directed to the management of the company, asking appropriate persons from the respective department (finance and accounting or directly from the controlling/analyses/management accounting department) to fill in the questionnaire, 40 companies correctly completed the questionnaire $(3.33 \%)$.

The vast majority of the surveyed companies operate in the manufacturing sector (63\%). The surveyed entities were both larger companies (with over 500 employees), and small and medium companies, which accounted for 55\%. Most respondents represented companies with foreign capital. Only $20 \%$ were Polish companies.

The first area in which the convergence was examined was budgeting and planning. Over half of the surveyed companies assessed the level of convergence between financial accounting and management accounting as very high in the process of short-term planning (55\% of the respondents) and medium-term planning (50\% 
of the respondents). The level of compliance of the management control system structure with the structure imposed by the accounting standards was also assessed as relatively high in the area of planning and budgeting (50\% of the surveyed companies). The results obtained in this area are presented in Table 1. It is worth noting that, in the case of the German companies surveyed by Weißenberger and Angelkort [2011], the average scores were even higher. For example, convergence in the area of short-term and medium-term budgeting and planning was assessed at 4.08 and 4.05 (compared to 3.5 and 3.6, respectively, in our study). The assessment of the level of compliance of the control structure for management purposes with the structure imposed by the accounting standards is the same in Poland and in Germany.

Table 1. Results of the study on convergence in the area of budgeting and planning

\begin{tabular}{|c|c|c|c|c|c|c|c|c|}
\hline \multirow{2}{*}{\multicolumn{3}{|c|}{$\begin{array}{l}\text { Assessment on a scale from } 0 \text { to } 5 \text {, where } 0 \\
\text { is a very low level, while } 5 \text { is a very high level: }\end{array}$}} & \multicolumn{6}{|c|}{$\%$ of responses } \\
\hline & & & \multicolumn{2}{|c|}{$\begin{array}{l}\text { (very) low } \\
\text { convergence }\end{array}$} & \multicolumn{2}{|c|}{$\begin{array}{c}\text { moderate } \\
\text { convergence }\end{array}$} & \multicolumn{2}{|c|}{$\begin{array}{l}\text { (very) high } \\
\text { convergence }\end{array}$} \\
\hline $\begin{array}{l}\text { Convergence in the area } \\
\text { of budgeting and planning }\end{array}$ & average & $\begin{array}{l}\text { standard } \\
\text { deviation }\end{array}$ & 0 & 1 & 2 & 3 & 4 & 5 \\
\hline $\begin{array}{l}\text { To what extent is short-term } \\
\text { planning and budgeting based } \\
\text { on methods of valuation } \\
\text { compliant with the accounting } \\
\text { standards? }\end{array}$ & 3.5 & 1.1 & $0 \%$ & $10 \%$ & $5 \%$ & $25 \%$ & $45 \%$ & $15 \%$ \\
\hline $\begin{array}{l}\text { To what extent is medium- } \\
\text { term planning and budgeting } \\
\text { based on methods of valuation } \\
\text { compliant with the accounting } \\
\text { standards? }\end{array}$ & 3.6 & 1.0 & $0 \%$ & $5 \%$ & $5 \%$ & $40 \%$ & $30 \%$ & $20 \%$ \\
\hline $\begin{array}{l}\text { What is the level of compliance } \\
\text { of the management control } \\
\text { system structure with the } \\
\text { structure imposed by the } \\
\text { accounting standards in } \\
\text { the area of planning and } \\
\text { budgeting? }\end{array}$ & 3.3 & 1.1 & $0 \%$ & $10 \%$ & $15 \%$ & $25 \%$ & $40 \%$ & $10 \%$ \\
\hline
\end{tabular}

Source: own study.

The next step was examining convergence in the area of reporting. In over half of the surveyed companies, the dates of financial reporting and management reporting are harmonised to a high or very high extent. The respondents declared that it is possible to harmonise items in the management report with the corresponding item of the financial report to a very high level ( $70 \%$ of the surveyed companies). The financial result for the purpose of management and the result of external reporting are also convergent to a large extent (65\% of the surveyed companies), but in only 
$45 \%$ of companies no adjustments or only one or two adjustments are needed for this purpose. It is worth noting that, in the surveyed companies, alternative costs and income are used for management reporting purposes to a moderate extent. This is most probably due to the fact that in order to ensure compliance of financial reporting and management reporting, this category was eliminated. As regards the harmonisation of reporting dates and the level of use of alternative income and costs,

Table 2. The results of the convergence study in the area of reporting

\begin{tabular}{|c|c|c|c|c|c|c|c|c|}
\hline \multirow{2}{*}{\multicolumn{3}{|c|}{$\begin{array}{l}\text { Assessment on a scale from } 0 \text { to } 5 \text {, where } 0 \\
\text { is a very low level, while } 5 \text { is a very high level: }\end{array}$}} & \multicolumn{6}{|c|}{$\%$ of responses } \\
\hline & & & \multicolumn{2}{|c|}{$\begin{array}{l}\text { (very) low } \\
\text { convergence }\end{array}$} & \multicolumn{2}{|c|}{$\begin{array}{l}\text { moderate } \\
\text { convergence }\end{array}$} & \multicolumn{2}{|c|}{$\begin{array}{l}\text { (very) high } \\
\text { convergence }\end{array}$} \\
\hline $\begin{array}{l}\text { Convergence in the area } \\
\text { of reporting }\end{array}$ & average & $\begin{array}{l}\text { standard } \\
\text { deviation }\end{array}$ & 0 & 1 & 2 & 3 & 4 & 5 \\
\hline $\begin{array}{l}\text { To what extent are financial } \\
\text { reporting and management } \\
\text { reporting dates harmonised? }\end{array}$ & 3.5 & 1.3 & $0 \%$ & $10 \%$ & $15 \%$ & $20 \%$ & $30 \%$ & $25 \%$ \\
\hline $\begin{array}{l}\text { To what extent are } \\
\text { alternative costs and income } \\
\text { used for management } \\
\text { reporting purposes? }\end{array}$ & 2.2 & 1.0 & $0 \%$ & $30 \%$ & $35 \%$ & $25 \%$ & $10 \%$ & $0 \%$ \\
\hline $\begin{array}{l}\text { To what extent can a given } \\
\text { item of a management } \\
\text { report be reconciled with } \\
\text { the corresponding item of } \\
\text { a financial report? }\end{array}$ & 3.8 & 1.0 & $0 \%$ & $5 \%$ & $5 \%$ & $20 \%$ & $45 \%$ & $25 \%$ \\
\hline $\begin{array}{l}\text { To what extent is the } \\
\text { financial result in the } \\
\text { management report } \\
\text { consistent with the financial } \\
\text { result in the financial } \\
\text { report? }\end{array}$ & 3.9 & 1.1 & $0 \%$ & $5 \%$ & $5 \%$ & $25 \%$ & $30 \%$ & $35 \%$ \\
\hline $\begin{array}{l}\text { How many adjustments } \\
\text { have to be made to reconcile } \\
\text { the financial result in } \\
\text { the financial report with } \\
\text { the financial result in } \\
\text { the management report? } \\
\text { (no adjustment }-5 \text {, } \\
1-2 \text { adjustments }-4 \text {, } \\
3-4 \text { adjustments }-3 \text {, } \\
5-7 \text { adjustments }-2 \text {, } \\
8-10 \text { adjustments }-1 \text {, } \\
\text { over } 10 \text { adjustments }-0 \text { ) }\end{array}$ & 3.0 & 1.7 & $10 \%$ & $10 \%$ & $25 \%$ & $10 \%$ & $15 \%$ & $30 \%$ \\
\hline
\end{tabular}

Source: own study. 
the average assessments made by the German managers surveyed by Weißenberger and Angelkort [2011] were higher: in Poland, the average assessment of date harmonisation is 3.5, while in Germany it is 4.28; as regards the use of alternative costs and income, the Polish result was 2.2 , while in the other study it was 3.62. The average assessment of the level of reconciliation of particular items of the financial result was the same in Poland and in Germany (3.8). The compatibility assessment of this result in management reports and in financial reports was similar (3.9 in Poland and 4.2 in Germany). The results obtained in the area of reporting are presented in Table 2.

The study showed interesting results in regard to convergence in the remaining areas of the accounting system operation. In the case of measurements and assessment of achievements, half of the respondents indicated that the remuneration of managers depends on financial indicators to a moderate extent. However, the level of convergence in the area of the IT system application may be said to be relatively high. In most of the surveyed companies, both financial accounting and management accounting use the same IT systems. Although in most of the surveyed companies, financial and management accounting specialists report to the same person $(50 \%)$ and actively cooperate with each other $(65 \%)$, only in some of the companies controllers provide management information to accountants. Also in those areas, the level of convergence in German companies is higher than in Polish ones (the average concerning information exchange is 2.9 in Poland and 3.83 in Germany). Only regarding the use of ERP systems by both accounting systems, the level of convergence is similar. The results obtained in the remaining aspects of the accounting system operation are presented in Table 3.

The convergence index was calculated to summarise the study. In order to do so, it was necessary to calculate the average of the answers provided in a given group by each respondent and then calculate the response structure indicator for the three groups. The first (low) level of convergence covers average answers within the range of $0-2$, the next (moderate) level of convergence corresponds to the average answers within the range of 2-4, and the last (high) level of convergence refers to the range of 4-5. The ranges adopted here differ slightly from the ranges used in Weißenberger and Angelkort [2011], which were: $0-1.5 ; 1.5-3.5$ and 3.5-5. The table below contains the convergence indices.

In the areas of budgeting and planning, reporting and organisational aspects of the accounting system, we are dealing with a moderate level of convergence. The average assessments made by the respondents were 3.4, and over half of them were between 2 and 4 . A slightly stronger convergence may be observed in the case of the IT systems used (the average score is 3.6), and 55\% of the surveyed companies assessed this area at 4 to 5 . The area of performance measurement is characterised by the lowest level of convergence (an average assessment of 2.8). 
Table 3. The results of the study on convergence in other areas of the accounting system operation

\begin{tabular}{|c|c|c|c|c|c|c|c|c|}
\hline \multirow{2}{*}{\multicolumn{3}{|c|}{$\begin{array}{l}\text { Assessment on a scale from } 0 \text { to } 5 \text {, where } 0 \\
\text { is a very low level, while } 5 \text { is a very high level: }\end{array}$}} & \multicolumn{6}{|c|}{$\%$ of responses } \\
\hline & & & \multicolumn{2}{|c|}{$\begin{array}{l}\text { (very) low } \\
\text { convergence }\end{array}$} & \multicolumn{2}{|c|}{$\begin{array}{l}\text { moderate } \\
\text { convergence }\end{array}$} & \multicolumn{2}{|c|}{$\begin{array}{l}\text { (very) high } \\
\text { convergence }\end{array}$} \\
\hline Other aspects of integration & average & $\begin{array}{l}\text { standard } \\
\text { deviation }\end{array}$ & 0 & 1 & 2 & 3 & 4 & 5 \\
\hline $\begin{array}{l}\text { To what extent do } \\
\text { remunerations of managers } \\
\text { depend on indicators } \\
\text { calculated based on financial } \\
\text { reports? }\end{array}$ & 2.8 & 1.2 & $0 \%$ & $20 \%$ & $20 \%$ & $30 \%$ & $20 \%$ & $10 \%$ \\
\hline $\begin{array}{l}\text { Does your company have an } \\
\text { integrated IT system (ERP) in } \\
\text { place that provides data both } \\
\text { to the controlling/management } \\
\text { accounting department and } \\
\text { the financial accounting } \\
\text { department? }\end{array}$ & 3.9 & 1.3 & $0 \%$ & $5 \%$ & $15 \%$ & $15 \%$ & $15 \%$ & $50 \%$ \\
\hline $\begin{array}{l}\text { Does your company have } \\
\text { a database that contains } \\
\text { current and planned data } \\
\text { used both by the controlling/ } \\
\text { management accounting } \\
\text { department and by the } \\
\text { financial accounting } \\
\text { department? }\end{array}$ & 3.1 & 1.3 & $0 \%$ & $15 \%$ & $15 \%$ & $35 \%$ & $15 \%$ & $20 \%$ \\
\hline $\begin{array}{l}\text { Do both the controlling/ } \\
\text { management accounting } \\
\text { department and the financial } \\
\text { accounting department use } \\
\text { data from the same financial } \\
\text { and accounting system } \\
\text { (accounts, cost centres)? }\end{array}$ & 3.9 & 1.3 & $0 \%$ & $10 \%$ & $5 \%$ & $10 \%$ & $35 \%$ & $40 \%$ \\
\hline $\begin{array}{l}\text { Do financial controllers/ } \\
\text { controlling specialists and } \\
\text { accountants report to the same } \\
\text { manager? }\end{array}$ & 3.3 & 1.7 & $0 \%$ & $30 \%$ & $5 \%$ & $15 \%$ & $5 \%$ & $45 \%$ \\
\hline $\begin{array}{l}\text { Do the controlling/ } \\
\text { management accounting } \\
\text { department and the financial } \\
\text { accounting department } \\
\text { actively cooperate in your } \\
\text { company? }\end{array}$ & 3.8 & 1.2 & $0 \%$ & $10 \%$ & $0 \%$ & $25 \%$ & $35 \%$ & $30 \%$ \\
\hline $\begin{array}{l}\text { Does the controlling } \\
\text { department provide } \\
\text { management information } \\
\text { to the financial accounting } \\
\text { department? }\end{array}$ & 2.9 & 1.2 & $0 \%$ & $15 \%$ & $25 \%$ & $30 \%$ & $20 \%$ & $10 \%$ \\
\hline
\end{tabular}

Source: own study. 
Table 4. The results of the measurement of the convergence index

\begin{tabular}{|l|c|c|c|c|c|}
\hline Convergence in a given area: & average & $\begin{array}{c}\text { standard } \\
\text { deviation }\end{array}$ & $\begin{array}{c}0 \leq \text { index } \leq 2 \\
\text { (very) low }\end{array}$ & $\begin{array}{c}2<\text { index }<4 \\
\text { moderate } \\
\text { convergence }\end{array}$ & $\begin{array}{c}4 \leq \text { index } \leq 5 \\
\text { (very) high }\end{array}$ \\
\hline Budgeting and planning & 3.4 & 1.1 & $10 \%$ & $50 \%$ & $40 \%$ \\
\hline Reporting & 3.3 & 1.4 & $10 \%$ & $75 \%$ & $15 \%$ \\
\hline Performance measurement & 2.8 & 1.2 & $20 \%$ & $50 \%$ & $30 \%$ \\
\hline IT systems & 3.6 & 1.3 & $15 \%$ & $30 \%$ & $55 \%$ \\
\hline $\begin{array}{l}\text { Organisational aspects of } \\
\text { accounting systems }\end{array}$ & 3.3 & 1.4 & $5 \%$ & $80 \%$ & $15 \%$ \\
\hline
\end{tabular}

Source: own study.

\section{Conclusions}

The study presented in the article shows that the level of convergence of financial accounting and management accounting in Polish enterprises is moderate. This is lower than in the corresponding study conducted by Weißenberger and Angelkort [2011] on German companies (the results of the study were published six years ago, thus the current the level of convergence in German companies may be even higher). This level of convergence of accounting is highly insufficient. It may be assumed that this results in the excessive costs of accounting and the insufficient quality of information in financial reports. However, the results show a higher level of convergence in comparison with the study of Kabalski [2012], implying development in the researched area.

One of the limitations of our study is the limited number of surveyed companies. Consequently, it is worth undertaking further attempts to quantitatively measure the level of convergence of financial accounting and management accounting in Polish companies. It would be equally important and interesting to conduct qualitative studies (with the use of interviews and observations) presenting the convergence of accounting in particular companies and the barriers to achieving it. It may be assumed that these are technical, organisational, cultural, social and psychological barriers.

To sum up, it can be concluded that the convergence of accounting in companies operating in Poland is still an unexplored area of research, however important for both cognitive and practical reasons. 


\section{Bibliography}

Dani A.C., Beuren I.M., 2014, Nivel de integração dos sistemas de contabilidade financeira e gerencial com o processo de convergência contábil e a efetividade da controladoria, Journal of Education and Research in Accounting, vol. 8, no. 3.

Joseph N., Turley S., Burns J., Lewis L., Scapens R.W., Southworth A., 1996, External financial reporting and management information: a survey of U.K. management accounts, Management Accounting Research, 7, pp. 73-93.

Kabalski P., 2012, Wybrane problemy stosowania Międzynarodowych Standardów Sprawozdawczości Finansowej w Polsce. Organizacja, kultura, osobowość, język, Wydawnictwo Uniwersytetu Łódzkiego, Łódź.

Procházka D., 2011, The Development of Financial and Management Accounting after the IFRS Adoption: A Case from the Czech Republic, http://ssrn.com/abstract=1660122.

Sobańska I., 2010, Rozwój rachunkowości zarządczej w Polsce po 1990 r., [in:] Sobańska I. (ed.), Rachunkowość zarzadcza. Podejście operacyjne i strategiczne, C.H. Beck, Warszawa.

Taipaleenmäki J., Ikäheimo S., 2009, On the Convergence of Financial Accounting and Management Accounting, 24 April 2009, http://ssrn.com/abstract=1394373 or http://dx.doi.org/10.2139/ ssrn.1394373 (15.05.2015).

Weißenberger B.E., Angelkort H., 2007, Controlling under IFRS in Austria - Empirical Results from Austrian IFRS Users (manuscript).

Weißenberger B.E., Angelkort H., 2011, Integration of financial and management accounting: the mediating influence of a consistent financial language on controllership effectiveness, Management Accounting Research, vol. 22, pp. 160-180.

Zarzycka E., 2016, Koncepcje i tendencje rozwoju zawodu specjalisty rachunkowości zarządczej. Wymiar krajowy i międzynarodowy, Wydawnictwo Uniwersytetu Łódzkiego, Łódź.

\section{KONWERGENCJA RACHUNKOWOŚCI FINANSOWEJ I ZARZĄDCZEJ W POLSCE}

Streszczenie: Celem artykułu było określenie stopnia konwergencji rachunkowości finansowej i rachunkowości zarządczej w przedsiębiorstwach w Polsce. Do zbadania stopnia konwergencji wykorzystano metodę sondażową z zastosowaniem kwestionariusza ankiety. Okazało się, że poziom konwergencji rachunkowości $\mathrm{w}$ badanych przedsiębiorstwach jest umiarkowany. Badania konwergencji rachunkowości na świecie nie są liczne, a w Polsce - zupełnie wyjątkowe. $Z$ tego względu badanie prezentowane w artykule jest istotne zarówno dla nauki, jak i dla praktyki rachunkowości.

Słowa kluczowe: konwergencja, rachunkowość finansowa, rachunkowość zarządcza, pomiar. 